\title{
Relationship Between Knowledge and Nurse Characteristics with the Completeness of Nursing Documentation in Inpatient Room of Bandung Muhammadiyah Hospital
}

\author{
$1^{\text {st }}$ Rahmat \\ Sekolah Tinggi Ilmu Kesehatan \\ 'Aisyiyah Bandung \\ Indonesia \\ syifataini.sastro17@gmail.com
}

\author{
$2^{\text {nd }}$ Dewi Mustikaningsih \\ Sekolah Tinggi Ilmu Kesehatan \\ 'Aisyiyah Bandung \\ Indonesia
}

\author{
$3^{\text {rd }}$ Tamara Oktaviani Rusmawan \\ Sekolah Tinggi Ilmu Kesehatan \\ 'Aisyiyah Bandung \\ Indonesia
}

\begin{abstract}
Nurses are obliged to document the nursing care. Documenting that is not done completely can reduce the quality of nursing service because it can not identify the extent of success level of nursing care that has been given and also a legal aspect because it can not be accountable to the client. This study aims to determine the relationship between the level of knowledge and characteristics of nurses with the completeness of nursing care documentation in Inpatient Room Muhammadiyah Hospital Bandung. This research design uses quantitative descriptive design with correlation method. Sampling technique using nonprobability sampling with purposive sampling.Data samples obtained through questionnaire and observation sheet. The data were analyzed through univariate by using the frequency and bivariate distribution using Chi Square Test. The research result from 66 respondents was 20-30 years old $(53,0 \%)$, last education majority of Nursing Diploma 50 people $(\mathbf{7 5 , 7 \%})$, Type Sex majority of women 51 people $(\mathbf{7 7 . 2 8} \%)$, and long working nurse majority $<10$ years 43 people $(65.2 \%)$. Based on the result of bivariate analysis showed that there is correlation of nurse knowledge level with the completeness of nursing documentation documentation with Chi Square value $(97,515)$ bigger than Chi Square table $(49,273)$ with significance value $(0,00)$ $<(0,05)$. Suggestions to achieve the completeness of nursing care documentation need to evaluate the training of nursing care documentation, especially for hospitalized ward nurses.
\end{abstract}

\section{Keywords-Nurse, Characteristics, documentation}

\section{INTRODUCTION}

Nursing documentation is one of the most important functions of nurses since the time of Florence Nightingle. Currently the health care system requires documentation that ensures continuity of care, completes legal evidence, nursing processes and supports the quality of patient care, nurses who are not compliant in documenting nursing care will result in poor quality of completeness of nursing care documentation. The Ministry of Health of the Republic of Indonesia sets standards for nursing care (SAK) of $90 \%$.
Documentation is an activity recording events and activities carried out in the form of providing services that are considered very valuable and important[1]. The two main forms of communication in nursing are verbal handover reports and written nursing documents. Documentation is any written information about a client that describes the care or services provided to that client [2]. Nursing care documentation is a prerequisite for quality of care [3]. Health is a fundamental right of every individual declared globally in the WHO constitution. To fulfill these rights in the last decade, it was agreed that the global commitment of Sustainable Development Goals (SDGs) which states that health development is the base of intelligence, productivity, and human welfare[4].

Nursing documentation is a record that contains all the information needed to determine the nursing diagnosis, carry out and evaluate nursing actions that are arranged in a systematic, valid and morally and legally responsible manner[5] . Documentation of nursing care becomes important as evidence of responsibility and accountability of nurses in carrying out their duties. Professional nurses are faced with a demand for higher responsibility and accountability for every action carried out from various possible problems experienced by patients both the problem of satisfaction with the services provided.

Documentation is an essential tool in the nursing profession, providing the structural, consistent, and effective communication required for the delivery of quality patient care that meets professional and legal standards[6].

In relation to the documentation of nursing care, a study by (Bara, 2014) on the relationship of nurses' motivation to the documentation of nursing care in the inpatient room at Pasar Rebo Regional Hospital showed the characteristics of the implementing nurses in the inpatient care of Pasar Rebo Regional Hospital, some 
were $<30$ years old, female sex, DIII / DIV education, working time $<5$ years, and civil servant employment status [1]. Whereas more than half of the motivation of implementing nurses in the inpatient market at Pasar Rebo Hospital is good. More than half of the nurses in the inpatient care at Pasar Rebo Regional Hospital conduct poor documentation of nursing care. From this study it was found that there was a significant relationship between the intrinsic motivation of implementing nurses with the implementation of documentation of nursing care in the inpatient room at Pasar Rebo Hospital with a value of $\mathrm{p}=0.043$ and there was a significant relationship between the extrinsic motivation of implementing nurses and the implementation of documentation of nursing care in the inpatient market of RSUD Pasar Rebo Rebo with a value of $\mathrm{p}=0.007$. Nurses are "the carring profession" having an important position in producing quality health services in hospitals, because the services they provide are based on a bio-psychosocial-spiritual approach that is unique and is carried out 24 hours a day and continuity is a distinct advantage compared to other services[4]. Muhammadiyah Hospital Bandung (RSMB) is a type C Islamic based hospital with 228 nurses. RSMB has a vision in the field of nursing that is the realization of nursing services that is the realization of excellent and Islamic nursing services that are superior at the level of West Java in 2018. RSMB nursing mission is to organize professional and Islamic-based nursing services IT (Information Technology), providing nursing care in accordance with authority , responsibilities and professional ethics, providing and developing Islamic and professional nursing resources as needed, planning and providing nursing facilities and infrastructure, monitoring and evaluating nursing services, and increasing the value of Islamic nursing services.

Based on a preliminary study by researchers on March 14-15, 2017, it is known from interviews with the nursing sector that training of nursing care documentation has never been held because it is constrained by something, only case studies have been conducted which are distributed to be filled in to representatives of each room. Based on interviews of six nurses, four nurses said they had never attended documentation training, two nurses said they had attended nursing care documentation training but while working in another hospital. Meanwhile, the socialization of nursing care documentation to the six nurses said that from the nursing department they like to come once a month to each room to socialize about nursing care documentation. Based on data obtained from the nursing field, the results obtained in the first quarter of 2017 for assessment (70.2\%), diagnosis $(71.75 \%)$, planning $(70.4 \%)$, implementation $(63.16 \%)$ and evaluation $(33.5 \%)$. This means that for the completeness of the assessment has not reached a percentage that is $(80 \%)$, diagnosis has not reached a percentage $(79 \%)$, planning has not reached a percentage (79\%), implementation has not reached a percentage (71\%), and evaluation has not reached a percentage (37\%) $\%)$. This means that it has not reached the set percentage of the Bandung Muhammadiyah Hospital standards.
Based on data from the field of nursing services for completeness of nursing care documentation in inpatient rooms in 2016, Multazam 2 (88.1\%), Multazam 3 (84.7\%), Multazam 4 (85.1\%), Multazam 5 (88.7\%), Arafat (89.6\%), Raudhoh 3 (88.5\%), Raudhoh 4 (91.4\%), Raudhoh $5(85.7 \%)$ and Dewi Sartika (89.2\%). This means that for the completeness of the documentation of nursing care in the inpatient room of the Bandung Muhammadiyah Hospital is incomplete because it has not yet reached the standard of completeness of the nursing care documentation in the Muhammadiyah Hospital Bandung, namely $(91.7 \%)$.

\section{METHOD}

The design of this study uses a quantitative descriptive design with the correlation method. The sampling technique uses nonprobability sampling with the type of purposive sampling. Data are obtained through questionnaires and observation sheets. Data were analyzed through univariate using frequency distribution and bivariate using Chi Square Test.

This type of research aims to determine whether there is a relationship between the level of knowledge of nurses with the completeness of nursing care documentation in the Inpatient Room of the Bandung Muhammadiyah Hospital.

\section{RESULT}

The population in this study were nurses both women and men who worked in the inpatient room of the Bandung Muhammadiyah Hospital (RSMB) totaling 127 nurses. In this study, researchers used a purposive sampling technique, the sample needed in this study was 66 respondents. Criteria for inclusion of implementing nurses working in the Inpatient Room Classes 1,2 and 3 (Multazam 2, Multazam 3, Multazam 4, Multazam 5 and Arafat) in RSMB.

The majority of education level is Diploma Nursing 50 people $(75.7 \%)$, the majority of female sex is 51 people $(77.28 \%)$, and the majority of working time nurses $<10$ years 43 people $(65.2 \%)$.

TABLE I. ANALYSIS OF THE COMPLETENESS OF THE DOCUMENTATION NURSING CARE WITH

CHARACTERISTICS OF RESPONDENTS IN THE INPATIENT ROOM MUHAMMADIYAH HOSPITAL BANDUNG

\begin{tabular}{|l|c|c|}
\hline \multicolumn{1}{|c|}{ Characteristics } & Total & Note \\
\hline Age & 0,325 & $0,325.0,05$ \\
Significance & 6,958 & \\
Chi Square Test & & \\
\hline Gender & 0,8885 & $0,885>0,05$ \\
Significance & 648 & \\
Chi Square Test & & \\
\hline Education level & 0,955 & $0,955>0,05$ \\
Significance & 1,568 & \\
$\quad$ Chi Square Test & & \\
\hline Length of work & 0,227 & $0,227>0,05$ \\
Significance & 4,338 & \\
$\quad$ Chi Square Test & & \\
\hline
\end{tabular}

Based on the table above, it can be seen that the age value of $p$-value verification is $0.325>0.05$, then the hypothesis is rejected, meaning that there is no relationship between age and the completeness of nursing care documentation, based on sex, the value of 
verification is $0.885>0.05$, then the hypothesis is rejected, means no. there is a relationship between sex with the completeness of nursing documentation, and based on education the significance value is $0.955>0.05$ then the hypothesis is rejected which means there is no relationship between education and completeness of the documentation. For a long time working p-value with a verification of $0.227>0.05$ then the hypothesis is rejected means the length of work also has no relationship with the completeness of nursing input documentation

TABLE II. ANALYSIS OF NURSE KNOWLEDGE LEVEL WITH THE COMPLETENESS OF NURSING CARE DOCUMENTATION IN INPATIENT ROOM OF BANDUNG MUHAMMADIYAH HOSPITAL 2017

\begin{tabular}{|c|r|r|}
\hline Variable & Significance & Chi Square \\
\hline Relationship between & & \\
Nurse Knowledge Level & 0,00 & 97,515 \\
and Nursing Care \\
Documentation \\
Completeness
\end{tabular}

Based on the results of the bivariate analysis test shows there is a relationship between the level of nurses' knowledge with the completeness of nursing care documentation with a Chi Square value (97.515) greater than the Chi Square table (49.273) with a significance value $(0.00)<(0.05)$. Then the hypothesis is accepted which means there is a relationship between the level of knowledge of nurses with the completeness of nursing care documentation

\section{DISCUSSION}

Univariate results show that the age of implementing nurses in Inpatient Rooms Classes 1,2 and 3 (Multazam 2, Multazam 3, Multazam 4, Multazam 5, and Arafat) in RSMB, shows that the age of 20-30 years is more that is equal to 35 respondents ( $53.0 \%$ ). Whereas for the sexes show that female sex more than the male sex that is equal to 51 respondents (77.2\%). in Retyaningsih Ida Wati, 2013), said the assumptions of young adult nurse age researchers in general they lack a sense of responsibility, lack discipline, often move -move jobs, have not been able to show the maturity of the soul, and have not been able to think rationally. Young nurses still need guidance and direction in being disciplined and inculcated with a sense of responsibility so that the utilization of productive age can be maximized[7]. That old age is generally more responsible and more conscientious compared to younger age, this happens the possibility of younger age being less experienced. For gender the results of the study are in line with research (Retyaningsih Ida Wati, 2013) [7], the work of nurses is more in demand by women because women are identified according to work with an honest, caring, gentle, patient attitude.

The work environment can make a person gain experience and knowledge both directly and indirectly. Someone will achieve certain satisfaction if he is able to adjust to the environment. The longer a person works they tend to be more satisfied with their work.

\section{A. Nurse Knowledge Level Based on Respondent Characteristics}

The results showed that the characteristics of respondents in the Inpatient Room Classes 1,2 and 3 (Multazam 2, Multazam 3, Multazam 4, Multazam 5 and Arafat) in the RSMB in the good category, according to the gender category were more women by 51 respondents (ie $77.28 \%$ ) included a good level of knowledge, Based on the level of nursing diploma education more While according to age, showed that the age of 20-30 years was more that is equal to 35 respondents $(53.0 \%)$ including the level of good knowledge. And for long time working nurses $<10$ years more that is equal to 43 respondents $(65.2 \%)$

The results of previous studies related to the knowledge of the documentation under study (Dwi, 2014) ,obtained the results of documentation research conducted in the inpatient room. In the Salatiga BPRSUD which examined the relationship of knowledge, attitudes and motivation with nursing documentation with nurses 'knowledge of $40 \%$ documentation, nurses' attitudes $55 \%$, and nurse motivation 53\%, and the results of implementing nursing documentation showed 43\%[8].

B. Analysis of the relationship between nurses' knowledge level and respondent characteristics

It can be seen that the age significance value of $p$-value is 0.199 and Chi Square value is 13.465. Because the significance value is 0.199> (0.05), the hypothesis is rejected, which means there is no relationship between age and the level of knowledge of nurses. Based on gender, the significance value of $\mathrm{p}$-value was 0.663 and Chi Square was 3.239. Because the significance value is $0.663>(0.05)$, the hypothesis is rejected, which means there is no relationship between sex with the level of knowledge of nurses, and based on education that the significance value is 0.997 and Chi Square is 1.936 . Because the significance value is $0.997>(0.05)$, the hypothesis is rejected, which means there is no relationship between education and the level of knowledge of nurses.

Multiple factors can affect the quality of nursing documentation, including the level of staffing, and education and training of nurses [9]. saying nurses' knowledge and characteristics (age, years of service, and training) have a significant relationship with the application of good supportive attitude about patient safety programs. the value is known to be the relationship of age with a supportive attitude of 4.84 , the strength of tenure with a supportive attitude of 0.015 , the strength of the training relationship with a supportive attitude of 0.086 , the strength of the relationship of knowledge with a supportive attitude of 65 .

C. Analysis of the Relationship Level between Nurses'

Knowledge and Nursing Care Documentation Completeness

Chi Square results $(97,515)$, this indicates there is significance, because the Chi Square results are greater than the Chi Square table $(49,273)$. Because the Chi Square results are greater than the Chi Square tables so that the results of the relationship between the level of 
knowledge and the completeness of the documentation of nursing care are obtained with a significance value (0.00) smaller than (0.05). The results of the study are in line with the research, entitled Nurses 'Knowledge and Attitudes towards the Completeness of Nursing Care Documentation at $\mathrm{H}$. Hospital. The test results of the analysis said there was a significant relationship between nurses' knowledge and documentation of nursing care $(\mathrm{p}=$ 0.044).

In the Salatiga BPRSUD that examined the relationship of knowledge, attitudes and motivation with nursing documentation with the nurse's knowledge of $40 \%$ documentation, nurse attitude $55 \%$, and nurse motivation $53 \%$, and the results of implementing nursing documentation showed $43 \%$. Based on the data obtained the complete data of nursing care documentation for assessment $(80.2 \%)$, diagnosis $(79.0 \%)$, planning $(76.4 \%)$, implementation (71.0\%) and evaluation (35.5\%). This means that for the completeness of the assessment has reached a percentage that is $(80 \%)$, the diagnosis has reached a percentage $(79 \%)$, planning has not reached a percentage $(79 \%)$, the implementation has reached a percentage $(71 \%)$, and the evaluation has not reached a percentage $(37 \%) \%)$ [8]. This means that some of the completeness of nursing care documentation reaches a predetermined percentage of the Bandung Muhammadiyah Hospital standards. These results are in line with research (Yuanita, 2009) [, entitled Workload and Work Motivation of Nurses with Complete Nursing Documentation in the Maternity Room and Children Hospital of Nyai Ageng Pinatih Gresik. The results of the study address the relationship of workload with the completeness of nursing care documentation $(\mathrm{p}=0.006)$ and the relationship of work motivation with the completeness of nursing documentation $(p=0.007)$ [10]. A nurse must be able to carry out nursing care documentation in the medical record completely, clearly, accurately and can be understood by others. To support effective nursing care, documentation that does not directly support patient care should be minimized or eliminated, and alternative options for recording nonpatient care-related information should be sought. Electronic health information management, in the form of EHRs, offers the promise of efficient and improved interdisciplinary collaboration through data availability and information synthesis as well as enhanced patient safety through decision support [11].

\section{CONCLUSIONS}

Based on the results of research and discussion of the relationship between the level of knowledge and characteristics of nurses with the completeness of nursing care documentation in the Inpatient Room of the Bandung Muhammadiyah Hospital it was concluded about the characteristics of respondents according to gender categories in the Inpatient Room of the Muhmmadiyah Hospital in Bandung, showing that there were more female sexes, namely 51 respondents $(77.28 \%)$, with more diploma level of nursing education that is 50 respondents $(75.7 \%)$, with ages $20-30$ years that is 35 respondents $(53.0 \%)$, and for length of work $<10$ years namely 43 respondents $(65.1 \%)$. Regarding the characteristics of respondents based on the level of knowledge of nurses in the Inpatient Room Bandung Muhammadiyah Hospital included in both categories. And the study results obtained There is no relationship between the Completeness of Nursing Care Documentation with Characteristics of Respondents in the Inpatient Room of Bandung Muhammadiyah Hospital, but there is a relationship between the Level of Nurse Knowledge and the Completeness of Nursing Care Documentation in the Inpatient Room of Bandung Muhammadiyah Hospital.

\section{ACKNOWLEDGMENT}

We would like to thank those who have assisted in the implementation process until the completion of this research, to SekolahTinggiIlmuKesehatan 'Aisyiyah Bandung as the funder of this research. We also thank Muhammadiyah Bandung Hospitalfor providing opportunities and assisting us in data collection. Finally, we thank all parties and colleagues atSekolahTinggillmuKesehatan 'Aisyiyah 'Aisyiyah Bandung for their support and motivation.

\section{REFERENCES}

[1] M. Bara and B. Suryati, "Hubungan Motivasi Perawat dengan Pelaksanaan Pendokumentasian Asuhan Keperawatan di Ruang Rawat Inap RSUD Pasar Rebo," J. Heal. Qual., vol. 5, no. 1, pp. 1-66, 2014.

[2] and C. B. John, Sanjay K., "Documentation guidelines based on expectation of documentation helps accurate documentation among nurses in psychiatric settings," Asian J. Nurs. Educ. Res., vol. 6 , no. 2

[3] P. F. Tuinman, A., de Greef, M. H., Krijnen, W. P., Paans, W., $\&$ Roodbol, "Accuracy of documentation in the nursing care plan in long-term institutional care," Geriatr. Nurs. (Minneap)., vol. 38 , no. $6,2017$.

[4] M. Andriani and R. Fitri, "Hubungan Kinerja Perawat Dalam Pendokumentasian Askep dengan Kepuasan Pasien Terhadap Pelayanan yang Diberikan di Ruang Rawat Inap RSUD Kota Solok tahun 2013,' 'AFIYAH, vol. 1, no. 1, 2014

[5] A. Mtsha, "Documentation of nursing care current practices and perceptions of nurses in a teaching hospital in Saudi Arabia." Stellenbosch: University of Stellenbosch, 2009.

[6] O. A. Alkouri, A. J. AlKhatib, and M. Kawafhah, "Importance and implementation of nursing documentation: review study," Eur. Sci. J., vol. 12, no. 3, 2016.

[7] R. I. Yanti and B. E. Warsito, "Hubungan karakteristik perawat, motivasi, dan supervisi dengan kualitas dokumentasi proses asuhan keperawatan," J. Manaj. Keperawatan, vol. 1, no. 2, 2013.

[8] N. Dwi, "Hubungan Pengetahuan dan Sikap Perawat terhadap Kelengkapan Dokumentasi Asuhan Keperawatan di Rumah Sakit H.," 2014, 2014. [Online]. Available: http://lib.ui.ac.id/naskahringkas/2016-09/S54304-Dwi Nuryani. [Accessed: 08-May-2017].

[9] J. Lindo et al., "An audit of nursing documentation at three public hospitals in Jamaica," J. Nurs. Scholarsh., vol. 48, no. 5, pp. 499-507, 2016.

[10] Y. Syaiful and E. Mujafafa, "Beban Kerja Dan Motivasi Kerja Perawat Dengan Kelengkapan Dokumentasi Keperawatan," Journals Ners Community, vol. 3, no. 1, pp. 58-65, 2012.

[11] B. N. Saleem, J. J., Flanagan, M. E., Wilck, N. R., Demetriades, J., \& Doebbeling, "The next-generation electronic health record: Perspectives of key leaders from the US Department of Veterans Affairs," J. Am. Med. Informatics Assoc. 20(e1), vol. 20, no. 1, 2013. 